\title{
Pengaruh Pemupukan Nitrogen dan Umur Tanaman terhadap Produksi dan Kualitas Rumput Kume (Sorghum plumosum var. timorense)
}

\section{The Effects of Nitrogen Fertilization and Plant's Age on The Quality and Production of Kume Grass (Sorghum plumosum var. timorense)}

\author{
F. K. Keraf ${ }^{1}$, Y. Nulik ${ }^{2}$ dan M. L. Mullik ${ }^{2}$ \\ ${ }^{1}$ Post graduate program of Animal Husbandry, Nusa Cendana University, Kupang \\ ${ }^{2}$ Animal Husbandry Faculty, Nusa Cendana University, Kupang \\ email: keraffabianus@gmail.com
}

(Diterima: 11 Desember 2014; Disetujui: 11 Maret 2015)

\begin{abstract}
ABSTRAK
Penelitian ini bertujuan untuk mengetahui produksi dan kualitas sorghum plumosum var. timorense dengan pemberian pupuk nitrogen dan umur tanaman. Rancangan yang digunakan adalah Rancangan Acak Lengkap (RAL) pola faktorial dengan 4 level pupuk nitrogen (faktor 1) dan 6 level umur tanaman (faktor 2) yang diulang 4 kali. Parameter yang diamati adalah laju pertumbuhan, jumlah anakan, produksi biomasa, kandungan nutrisi dan kecernaan in vitro. Data yang diperoleh dianalisis menggunakan analisis variansi dimana hasil penelitian menunjukkan bahwa pupuk nitrogen berpengaruh nyata $(\mathrm{P}<0,05)$ terhadap produksi bahan kering dan produksi serat kasar, namun berpengaruh sangat nyata $(\mathrm{P}<0,01)$ terhadap laju pertumbuhan, jumlah anakan, produksi bahan organik, produksi protein kasar, kecernaan bahan kering dan kecernaan bahan organik. Sedangkan faktor umur tanaman berpengaruh sangat nyata $(\mathrm{P}<0,01)$ terhadap semua parameter yang diamati. Interaksi kedua faktor tidak berpengaruh $(P>0,05)$ terhadap jumlah anakan, produksi bahan kering, produksi bahan organik dan produksi serat kasar, namun berpengaruh $(\mathrm{P}<0,5)$ terhadap laju pertumbuhan, produksi protein kasar dan berpengaruh sangat nyata $(\mathrm{P}<0,01)$ terhadap kecernaan bahan kering dan kecernaan bahan organik.
\end{abstract}

Kata kunci: rumput kume, pupuk nitrogen, umur tanaman

\section{ABSTRACT}

The research was conducted to evaluate the effects of nitrogen fertilization and plant's age on the quality and production of Kume grass (Sorghum plumosum var. timorense).This experiment used Factorial completely randomized design. The first factor was nitrogen fertilizers dose, the second factor was different level of grass' age, with four replications. Several important parameters consisted of growth rate, the number of tillers, biomass production, nutrient content and in vitro digestibility were measured and recorded during the reserch. Data were analyzed by analysis of varian. The result showed that the nitrogen fertilizers significantly $(P<0,05)$ influenced the production of both grass dried material and crude fiber while highly significantly $(P<0,01)$ influenced the growth rate, the number of tillers, the production of organic material, the production of crude protein, and the digestibility of both dry and organic matter. The result also indicated that all the observed parameters were highly significatly $(P<0,01)$ influenced by the age of the grass. Further analysis showed that interection between the two factors had no effect $(P>0,05)$ on the number of tillers, dry matter production, the production oforganic material and the production ofcrude fiber. However, it had a significant effect $(P<0,5)$ on the rate of grass' growth, the production of crude protein and highly significant effect $(P<0,01)$ on dry and organic matter digestibility.

Keywords: kume grass, nitrogen fertilizers, age of plant 


\section{PENDAHULUAN}

Salah satu pakan lokal yang ada di pulau Timor adalah Sorghum plumosum var. timoorense (rumput kume) yang sudah beradaptasi dengan baik pada kondisi lingkungan kering. Rumput ini dapat tumbuh dengan baik ketika memasuki musim hujan dan akan bertahan dalam beberapa bulan saja karena dipengaruhi oleh faktor lingkungan dimana rumput ini tumbuh. Produktivitas dari rumput yang tumbuh secara alamiah ini cukup tinggi secara kuantitas namun secara kualitas masih rendah (Dami Dato, 2009).

Kondisi NTT yang terkenal dengan lahan kering dan memiliki lahan marginal yang kurang subur, menyebabkan pertumbuhan tanaman kurang optimal. Dengan pertumbuhan yang kurang optimal maka akan menghasilkan produksi dan kualitas yang rendah pula. Oleh karena itu dalam membudidayakan rumput tersebut perlu diberi perlakuan pupuk nitrogen untuk menambah hara dalam tanah sebagai sumber makanan bagi tanaman dalam melaksanakan fungsi metabolisme dalam tubuh tanaman. Selain itu juga perlu ada penentuan umur tanaman yang ideal sehingga rumput s.plumosum var. timorense dapat menghasilkan hijauan pakan yang berkualitas dan produksi tinggi untuk memenuhi kebutuhan ternak secara berkelanjutan.

\section{METODE}

Penelitian dilaksanakan di green house seluas $45 \mathrm{~m}^{2}$ milik Balai Besar Pelatihan Peternakan Kupang, yang terletak di Jl. Timor Raya, desa Noelbaki, kecamatan Kupang Tengah, kabupaten Kupang, Nusa Tenggara Timur selama kurang lebih 9 bulan. Materi yang digunakan dalam penelitian ini adalah rumput kume (sorghum plumosum var. timorense) dalam bentuk pols, polybag berukuran $18 \times 23 \mathrm{~cm}$ dengan diameter $22 \mathrm{~cm}$, tanah sebagai media tanam dan pupuk urea sebagai sumber $\mathrm{N}(45 \%)$.

Selanjutnya tanah sebanyak $3 \mathrm{~kg}$ dimasukan kedalam masing-masing polybag sebanyak 96 unit yang ditata dalam green house dan ditanam anakan rumput kume sebanyak 2 anakan dalam setiap polybag. Penyiraman dilakukan setiap hari, dan pada minggu ke dua setelah penanaman dilakukan pemupukan nitrogen dengan dosis sesuai perlakuan. Pemanenan dilakukan dengan memotong setiap tanaman setinggi $10 \mathrm{~cm}$ dari permukaan tanah pada setiap 2 minggu sesuai perlakuan, yang diawali dengan menghitung jumlah anakan yang tumbuh serta mengukur tinggi tanaman dan dilanjutkan dengan pengukuran produksi segar serta melakukan preparasi sample untuk dilakukan analisis proksimat di Balai Penelitian Ternak CiawiBogor-Jawa Barat.

Penelitian ini menggunakan Rancangan Faktorial dengan 2 faktor perlakuan dan masing-masing diulang 4 kali, yaitu faktor pertama adalah level pupuk nitrogen $(\mathrm{N})$ yang terdiri dari: N0 : tanpa pupuk (kontrol), N5 : $50 \mathrm{~kg} / \mathrm{Ha}$ (setara dengan 0,43 g/polibag), N10 :100 kg/Ha (setara dengan 0,86 g/polibag) dan $\mathrm{N} 15 \quad: 150 \quad \mathrm{~kg} / \mathrm{Ha}$ (setara dengan 1,30 $\mathrm{g}$ /polibag). Faktor kedua adalah umur tanaman (M) yang terdiri dari M2: umur 2 minggu, M4: umur 4 minggu, M6: umur 6 minggu, M8: umur 8 minggu, M10: umur 10 minggu dan M12: umur 12 minggu. Hasil analisis akan diuji lanjut dengan Uji Jarak Berganda Duncan menurut Steel dan Torrie (1993).

\section{HASIL DAN PEMBAHASAN}

\section{Laju Pertumbuhan dan Jumlah Anakan}

Hasil analisis varian menunjukkan bahwa secara mandiri faktor pupuk $\mathrm{N}$ dan umur tanaman berpengaruh sangat nyata $(\mathrm{P}<0,01)$ terhadap laju pertumbuhan dan jumlah anakan, namun interaksi antara kedua faktor tersebut berpengaruh nyata $(\mathrm{P}<0,05)$ terhadap laju pertumbuhan dan tidak berpengaruh $(\mathrm{P}>0,05)$ terhadap jumlah anakan $S$. plumosum var. timorense dimana nilai probibilitas $\mathrm{N} * \mathrm{M}$ terhadap laju pertumbuhan tanaman sebesar 0,049 dan terhadap jumlah anakan sebesar 0,223.

Hasil uji lanjut Duncan menunjukkan bahwa perlakuan N10M6 memberikan 
Tabel 1. Laju pertumbuhan dan jumlah anakan rumput Sorghum plumosum var. timorense akibat perlakuan.

\begin{tabular}{|c|c|c|c|c|}
\hline \multicolumn{2}{|l|}{ Perlakuan } & \multirow{2}{*}{$\begin{array}{l}\text { Tinggi Tanaman } \\
(\mathrm{cm})\end{array}$} & \multirow{2}{*}{$\begin{array}{l}\text { Laju Pertumbuhan } \\
(\mathrm{cm} / \mathrm{hari})\end{array}$} & \multirow{2}{*}{$\begin{array}{l}\text { Jumlah anakan } \\
\text { (polls) }\end{array}$} \\
\hline Pupuk & Umur Tanaman & & & \\
\hline \multirow{6}{*}{$\begin{array}{l}\text { Tanpa Pupuk Nitrogen } \\
\qquad\left(\mathrm{N}_{0}\right)\end{array}$} & 2 Minggu $\left(\mathrm{M}_{2}\right)$ & 68,50 & $1,39 \pm 0,55^{\text {abcd }}$ & $8 \pm 2,22^{\mathrm{a}}$ \\
\hline & 4 Minggu $\left(\mathrm{M}_{4}\right)$ & 102,00 & $1,83 \pm 0,41^{\text {bcdefgh }}$ & $11 \pm 3,30^{\mathrm{ab}}$ \\
\hline & 6 Minggu $\left(M_{6}\right)$ & 162,50 & $2,54 \pm 0,73^{\text {hij }}$ & $14 \pm 4,20^{\mathrm{abcd}}$ \\
\hline & 8 Minggu $\left(\mathrm{M}_{8}\right)$ & 157,00 & $1,90 \pm 0,67$ bcdefgh & $14 \pm 5,32^{\mathrm{abcd}}$ \\
\hline & 10 Minggu $\left(\mathrm{M}_{10}\right)$ & 139,00 & $1,25 \pm 0,22^{\mathrm{abc}}$ & $15 \pm 5,80^{\text {abcdef }}$ \\
\hline & 12 Minggu $\left(\mathrm{M}_{12}\right)$ & 150,00 & $1,18 \pm 0,10^{\mathrm{ab}}$ & $11 \pm 4,57^{a b}$ \\
\hline \multirow{6}{*}{$\begin{array}{c}\text { Dosis Pupuk Nitrogen } 50 \\
\mathrm{~kg} / \mathrm{ha} \\
\left(\mathrm{N}_{5}\right)\end{array}$} & 2 Minggu $\left(\mathrm{M}_{2}\right)$ & 91,50 & $2,79 \pm 0,58^{\mathrm{ij}}$ & $13 \pm 1,50^{\mathrm{abc}}$ \\
\hline & 4 Minggu $\left(\mathrm{M}_{4}\right)$ & 117,75 & $2,20 \pm 0,57^{\text {efghi }}$ & $15 \pm 4,86^{\text {abcdef }}$ \\
\hline & 6 Minggu $\left(M_{6}\right)$ & 145,00 & $2,20 \pm 0,58^{\text {efghi }}$ & $20 \pm 6,02^{\text {abcdefg }}$ \\
\hline & 8 Minggu $\left(\mathrm{M}_{8}\right)$ & 155,00 & $1,76 \pm 0,08^{\text {abcdefg }}$ & $24 \pm 5,32^{\text {bcdefgh }}$ \\
\hline & 10 Minggu $\left(\mathrm{M}_{10}\right)$ & 156,25 & $1,51 \pm 0,32^{\text {abcde }}$ & $30 \pm 10,47^{\text {fghi }}$ \\
\hline & $12 \mathrm{Minggu}\left(\mathrm{M}_{12}\right)$ & 143,00 & $1,08 \pm 0,38^{\mathrm{a}}$ & $30 \pm 14,76^{\text {fghi }}$ \\
\hline \multirow{6}{*}{$\begin{array}{c}\text { Dosis Pupuk Nitrogen } 100 \\
\mathrm{~kg} / \mathrm{ha} \\
\left(\mathrm{N}_{10}\right)\end{array}$} & 2 Minggu $\left(\mathrm{M}_{2}\right)$ & 78,25 & $2,25 \pm 0,60^{\mathrm{ab}}$ & $9 \pm 4,11^{\mathrm{ab}}$ \\
\hline & 4 Minggu $\left(M_{4}\right)$ & 114,75 & $2,38 \pm 0,21^{\text {ghij }}$ & $18 \pm 5,06^{\text {abcdef }}$ \\
\hline & 6 Minggu $\left(M_{6}\right)$ & 171,75 & $2,93 \pm 0,32^{\mathrm{j}}$ & $20 \pm 6,99$ abcdefg \\
\hline & 8 Minggu $\left(\mathrm{M}_{8}\right)$ & 160,75 & $1,95 \pm 0,32^{\text {cdefgh }}$ & $29 \pm 16,18^{\text {defghi }}$ \\
\hline & 10 Minggu $\left(\mathrm{M}_{10}\right)$ & 161,50 & $1,61 \pm 0,23$ abcdef & $29 \pm 13,49^{\text {defghi }}$ \\
\hline & $12 \mathrm{Minggu}\left(\mathrm{M}_{12}\right)$ & 157,25 & $1,20 \pm 0,32^{\mathrm{ab}}$ & $38 \pm 8,69^{i j}$ \\
\hline \multirow{6}{*}{$\begin{array}{l}\text { Dosis Pupuk Nitrogen } 150 \\
\mathrm{~kg} / \mathrm{ha} \\
\left(\mathrm{N}_{15}\right)\end{array}$} & 2 Minggu $\left(\mathrm{M}_{2}\right)$ & 84,00 & $2,02 \pm 0,70^{\text {defgh }}$ & $11 \pm 4,97^{a b}$ \\
\hline & 4 Minggu $\left(M_{4}\right)$ & 122,75 & $2,54 \pm 0,38^{\text {hij }}$ & $21 \pm 3,77^{\text {abcdefg }}$ \\
\hline & 6 Minggu $\left(\mathrm{M}_{6}\right)$ & 171,25 & $2,75 \pm 0,25^{\mathrm{ij}}$ & $27 \pm 9,59^{\text {cdefghi }}$ \\
\hline & 8 Minggu $\left(\mathrm{M}_{8}\right)$ & 181,75 & $2,19 \pm 0,16^{\text {efghi }}$ & $40 \pm 9,43^{\mathrm{ij}}$ \\
\hline & 10 Minggu $\left(\mathrm{M}_{10}\right)$ & 155,50 & $1,87 \pm 0,28^{\text {bcdefgh }}$ & $35 \pm 10,34$ ghij \\
\hline & 12 Minggu $\left(\mathrm{M}_{12}\right)$ & & $1,26 \pm 0,19$ abc & $46 \pm 21,21^{\mathrm{hij}}$ \\
\hline SEM & & & 0,182 & 80,059 \\
\hline Probibilitas N & & & 0,005 & 0,000 \\
\hline Probibilitas M & & & 0,000 & 0,000 \\
\hline Probibilitas $N^{*} M$ & & & 0,049 & 0,223 \\
\hline
\end{tabular}

Keterangan : Subskrip pada kolom yang sama menunjukkan hasil yang berbeda nyata $(\mathrm{P}<0,05)$

laju pertumbuhan tertinggi sebesar 2,93 $\mathrm{cm} /$ hari dan berbeda dengan perlakuanperlakuan yang lain. Hasil penelitian ini membuktikan bahwa walaupun tanaman rumput S. plumosum var. timorense merupakan tanaman khas pulau timor dan mampu menyesuaikan dengan kondisi lingkungan, namun akan bertumbuh dengan baik jika dipacu dengan pupuk nitrogen untuk menunjang pertumbuhan dan perkembangan. Selain itu, umur tanaman yang tepat tanaman pakan ternak adalah 42 hari sesudah tanam, karena jika melewati umur tersebut, tanaman akan memasuki fase generatif sehingga unsur $\mathrm{N}$ yang terserap tanaman difokuskan pada pembentukan bunga dan biji tanaman. Hal ini sesuai dengan pendapat Salisburry dan Ross (1995) dikutip Sawen (2012), bahwa laju pertumbuhan tanaman secara linear berhubungan dengan nilai substrat hasil fotosintesis yang tersedia untuk pertumbuhan. Ada kemungkinan juga bahwa pertumbuhan tanaman yang lambat dipengaruhi oleh cekaman suhu dan berkurangnya ketersediaan air dalam tanah, seperti yang dikemukakan Sowmen et al. (2014) bahwa apabila 
Tabel 2. Produksi bahan kering, produksi bahan organik, produksi protein kasar dan produksi serat kasar rumput Sorghum plumosum var. timorense akibat perlakuan.

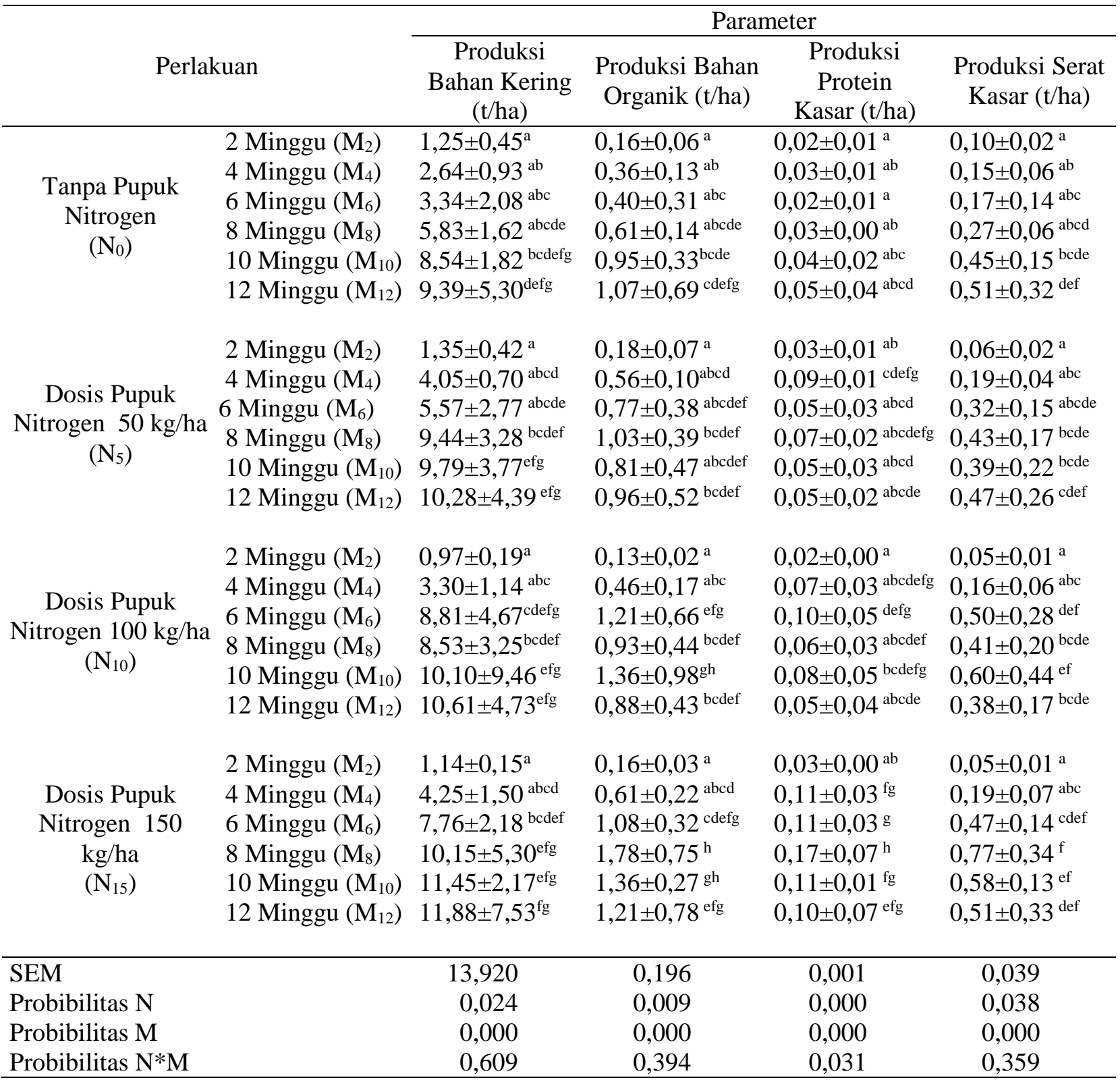

Keterangan : Subskrip pada kolom yang sama menunjukkan hasil yang berbeda nyata $(\mathrm{P}<0,05)$

jumlah air yang tersedia di tanah tidak mencukupi bagi kebutuhan tanaman maka tanaman akan mengalami gangguan morfologi dan fisiologis sehingga pertumbuhan dan produksinya akan terhambat.

Jumlah anakan tertinggi terdapat pada perlakuan N15M12 sebesar 46 anakan diikuti tidak berbeda $(\mathrm{P}>0,05)$ dengan perlakuanperlakuan yang lain. Hasil penelitian ini dimungkinkan karena dosis pemupukan nitrogen yang optimum dapat menyediakan unsur $\mathrm{N}$ dalam tanah untuk menunjang pertumbuhan tanaman. Ketersediaan nitrogen dalam tanah ini menyebabkan proses pembelahan sel akan semakin cepat terjadi. Hal ini sesuai dengan pendapat Afifi et al. (2011) bahwa aplikasi pupuk urea pada tanaman akan meningkatkan pertumbuhan tanaman dan sesuai dengan pendapat Bey dan Las (1991) bahwa pertumbuhan tanaman ditentukan oleh laju pembelahan dan pembesaran sel dan suplay bahan-bahan organik dan anorganik untuk sintesa protoplasma dan dinding sel yang baru. 


\section{Produksi Biomasa}

Hasil sidik ragam menunjukkan bahwa secara terpisah faktor pemupukan berpengaruh nyata $(\mathrm{P}<0,05)$ terhadap produksi $\mathrm{BK}$ dan SK sedangkan terhadap produksi BO dan PK berpengaruh sangat nyata. Faktor umur tanaman berpengaruh sangat nyata $(\mathrm{P}<0,01)$ terhadap produksi $\mathrm{BK}, \mathrm{BO}, \mathrm{PK}$ dan SK. Interaksi kombinasi antara kedua faktor tidak berpengaruh $(>0,05)$ terhadap produksi $\mathrm{BK}$, $\mathrm{BO}$, dan SK namun berpengaruh nyata $(\mathrm{P}<0,05)$ terhadap produksi PK. Besarnya produksi BK, BO, PK dan SK rumput $S$. plumosum var. timorense dapat dilihat pada Tabel 2.

Tabel 2 menunjukkan bahwa perlakuan N15M12 menghasilkan produksi bahan kering terbesar sebesar 11,88 ton/ha dan berbeda dengan perlakuan yang lain. Hal ini menunjukkan bahwa pada level pupuk yang tinggi dan umur panen yang lebih lama, unsur hara yang tersedia dapat memacu pertumbuhan dan perkembangan tanaman sehingga menghasilkan bahan kering lebih besar pula. Koten (2013) mengemukakan bahwa faktor umur panen, produksi BK tanaman bagian atas semakin meningkat dengan bertambahnya umur potong karena makin banyaknya waktu yang tersedia bagi tanaman untuk berfotosintesis maka makin banyak terjadi akumulasi material hasil fotosinteis didalam jaringan tanaman.

Meningkatnya produksi bahan organik seiring dengan meningkatnya produksi bahan kering, dimana produksi bahan organik tertinggi terdapat pada perlakuan N15M8 sebesar 1,73 ton/ha berbeda dengan perlakuanperlakuan yang lainnya. Hasil penelitian ini menjelaskan bahwa makin tinggi level pupuk maka makin tinggi pula produksi bahan orgnik tanaman. Hasil penelitian ini sesuai pendapat Salisbury dan Ross (1995) yang dikutip Koten (2013) bahwa komponen utama dalam berat kering tanaman adalah senyawa polysakarida dan lignin pada dinding sel, ditambah komponen sitoplasma seperti protein, lipid, asam amino dan asam organik. Selajutnya dijelaskan oleh Yoku et al. (2007) bahwa sorghum sebagai tanaman pakan ternak yang di pupuk nitrogen akan menghasilkan produksi $60 \%$ lebih banyak dari pada tidak dipupuk. Produksi BO yang tinggi ini juga merupakan ekspresi dari laju pertumbuhan yang tinggi.

Produksi PK dan SK tanaman juga meningkat seiring dengan meningkatnya produksi $\mathrm{BK}$ tanaman, sama halnya dengan produksi BO dimana perlakuan N15M8 menghasilkan produksi PK tertinggi sebesar 0,17 ton/ha yang berbeda nyata dengan perlakuan-perlakuan yang lainnya. Sedangkan produksi SK tertinggi juga terdapat pada perlakuan N15M8 yang berbeda dengan perlakuan-perlakuan yang lain. Hal ini terjadi karena peningkatan pupuk $\mathrm{N}$ dengan umur panen yang optimal akan meningkatkan biomasa tanaman, dan meningkatnya biomasa maka makin meningkat pula kandungan serat kasar dan protein kasar. Ifradi et al. (2012) juga mengemukakan bahwa dengan banyaknya unsur hara yang terserap oleh tanaman maka fotosintesis akan meningkat sehingga makin banyak pula karbohidrat yang dihasilkan oleh tanaman yang akan membantu pembentukan batang dan daun tanaman.

\section{Kandungan Nutrisi}

Hasil analisis proksimat pada laboratorium Nutrisi dan Pakan Ternak, Balai Penelitian Ternak Bogor, Jawa Barat tentang pengaruh level pupuk $\mathrm{N}$ dan umur tanaman terhadap kandungan nutrisi rumput $S$. plumosum var. timorense disajikan pada Tabel 3.

Total kandungan BK tertinggi sebesar $67,63 \%$ dan total kandungan SK tertinggi sebesar 39,37\% dari perlakuan N5M12. Kondisi ini terjadi karena tanaman yang masih muda mempunyai sel yang aktif sedangkan tanaman yang usia tua terjadi penebalan dinding sel yang mengakibatkan kandungan bahan kering meningkat. Semakin tua tanaman maka akan lebih sedikit kandungan airnya dan proporsi dinding selnya lebih tinggi dibandingkan dengan isi sel. Kandungan dinding sel yang semakin tinggi, maka tanaman tersebut akan lebih banyak mengandung bahan kering (Mansyur dkk., 2005). 
Tabel 3. Total kandungan bahan kering, bahan organik, protein kasar dan serat kasar rumput Sorghum plumosum var. timorense akibat perlakuan.

\begin{tabular}{|c|c|c|c|c|c|c|c|c|c|c|c|c|c|c|}
\hline \multirow{2}{*}{\multicolumn{2}{|c|}{ Perlakuan }} & \multicolumn{4}{|c|}{ Bahan Kering } & \multicolumn{3}{|c|}{ Bahan Organik } & \multicolumn{3}{|c|}{ Protein Kasar } & \multicolumn{3}{|c|}{ Serat Kasar } \\
\hline & & $\begin{array}{c}\text { Daun } \\
(\%)\end{array}$ & $\begin{array}{c}\text { Batang } \\
(\%)\end{array}$ & $\begin{array}{c}\text { Material } \\
\text { Kering }(\%)\end{array}$ & $\begin{array}{c}\text { Total } \\
(\%)\end{array}$ & $\begin{array}{l}\text { Daun } \\
(\%)\end{array}$ & $\begin{array}{c}\text { Batang } \\
(\%)\end{array}$ & $\begin{array}{c}\text { Total } \\
(\%)\end{array}$ & $\begin{array}{c}\text { Daun } \\
(\%)\end{array}$ & $\begin{array}{c}\text { Batang } \\
(\%)\end{array}$ & $\begin{array}{c}\text { Total } \\
(\%)\end{array}$ & $\begin{array}{c}\text { Daun } \\
(\%)\end{array}$ & $\begin{array}{c}\text { Batang } \\
(\%)\end{array}$ & $\begin{array}{c}\text { Total } \\
(\%)\end{array}$ \\
\hline \multirow{6}{*}{$\mathrm{N}_{0}$} & $\mathrm{M}_{2}$ & 25,62 & 15,62 & 86,79 & 26,06 & 91,39 & 92,55 & 87,82 & 12,41 & 02,11 & 9,72 & 30,20 & 47,25 & 32,54 \\
\hline & $\mathrm{M}_{4}$ & 28,36 & 26,28 & 90,32 & 28,96 & 91,39 & 92,55 & 89,70 & 12,41 & 02,11 & 7,73 & 30,20 & 47,25 & 36,74 \\
\hline & $\mathrm{M}_{6}$ & 45,91 & 32,17 & 90,57 & 44,61 & 88,70 & 93,17 & 78,48 & 09,72 & 01,99 & 3,99 & 35,02 & 42,66 & 34,28 \\
\hline & $\mathrm{M}_{8}$ & 62,07 & 37,25 & 93,90 & 38,28 & 88,70 & 93,17 & 72,29 & 09,72 & 01,99 & 2,95 & 35,02 & 42,66 & 32,09 \\
\hline & $\mathrm{M}_{10}$ & 65,00 & 40,75 & 94,86 & 46,61 & 84,30 & 92,55 & 74,56 & 09,14 & 02,11 & 2,79 & 32,82 & 46,97 & 36,34 \\
\hline & $\mathrm{M}_{12}$ & 68,75 & 55,68 & 96,44 & 64,62 & 84,30 & 92,55 & 76,43 & 09,14 & 02,11 & 3,15 & 32,82 & 46,97 & 36,85 \\
\hline \multirow{6}{*}{$\mathrm{N}_{5}$} & $\mathrm{M}_{2}$ & 17,11 & 13,97 & 84,91 & 17,87 & 92,54 & 93,40 & 90,51 & 18,38 & 09,48 & 15,35 & 29,73 & 33,53 & 30,10 \\
\hline & $\mathrm{M}_{4}$ & 27,94 & 25,64 & 91,05 & 28,35 & 92,54 & 93,40 & 90,89 & 18,38 & 09,48 & 14,23 & 29,73 & 33,53 & 30,68 \\
\hline & $\mathrm{M}_{6}$ & 38,42 & 31,67 & 91,82 & 34,95 & 90,18 & 93,96 & 90,60 & 11,65 & 03,21 & 5,34 & 27,20 & 44,26 & 32,68 \\
\hline & $\mathrm{M}_{8}$ & 61,75 & 36,53 & 94,21 & 36,18 & 90,18 & 93,96 & 73,05 & 11,65 & 03,21 & 3,96 & 27,20 & 44,26 & 32,79 \\
\hline & $\mathrm{M}_{10}$ & 63,92 & 39,91 & 94,82 & 47,41 & 84,38 & 90,92 & 69,57 & 10,03 & 03,28 & 3,45 & 27,26 & 48,79 & 34,91 \\
\hline & $\mathrm{M}_{12}$ & 67,15 & 54,47 & 96,15 & 67,63 & 84,38 & 90,92 & 65,43 & 10,03 & 03,28 & 3,42 & 27,26 & 48,79 & 39,37 \\
\hline \multirow{6}{*}{$\mathrm{N}_{10}$} & $\mathrm{M}_{2}$ & 16,93 & 13,40 & 78,53 & 17,68 & 92,24 & 93,97 & 90,62 & 15,16 & 11,41 & 14,34 & 32,70 & 33,01 & 32,09 \\
\hline & $\mathrm{M}_{4}$ & 27,68 & 24,36 & 90,23 & 27,85 & 92,24 & 93,97 & 90,91 & 15,16 & 11,41 & 13,56 & 32,70 & 33,01 & 32,12 \\
\hline & $\mathrm{M}_{6}$ & 35,10 & 27,42 & 91,08 & 31,53 & 89,17 & 93,13 & 89,51 & 12,13 & 04,33 & 6,79 & 29,38 & 43,66 & 34,88 \\
\hline & $\mathrm{M}_{8}$ & 38,07 & 31,99 & 92,48 & 31,60 & 89,17 & 93,13 & 79,94 & 12,13 & 04,33 & 5,19 & 29,38 & 43,66 & 35,19 \\
\hline & $\mathrm{M}_{10}$ & 42,22 & 37,06 & 95,27 & 37,35 & 86,09 & 91,86 & 71,68 & 11,83 & 03,87 & 4,28 & 27,69 & 42,84 & 35,52 \\
\hline & $\mathrm{M}_{12}$ & 59,43 & 42,85 & 95,66 & 58,72 & 86,09 & 91,86 & 66,64 & 11,83 & 03,87 & 3,65 & 27,69 & 42,84 & 37,79 \\
\hline \multirow{6}{*}{$\mathrm{N}_{15}$} & $\mathrm{M}_{2}$ & 15,31 & 13,26 & 84,67 & 15,39 & 92,54 & 93,82 & 92,10 & 18,60 & 11,53 & 16,80 & 27,94 & 33,39 & 28,99 \\
\hline & $\mathrm{M}_{4}$ & 25,72 & 21,26 & 89,81 & 24,97 & 92,54 & 93,82 & 92,09 & 18,60 & 11,53 & 16,35 & 27,94 & 33,39 & 29,30 \\
\hline & $\mathrm{M}_{6}$ & 34,09 & 27,10 & 91,03 & 30,95 & 90,10 & 91,81 & 89,58 & 14,41 & 05,74 & 09,07 & 35,34 & 43,65 & 29,63 \\
\hline & $\mathrm{M}_{8}$ & 37,36 & 29,79 & 93,61 & 28,97 & 90,10 & 91,81 & 77,94 & 14,41 & 05,74 & 07,28 & 35,34 & 43,65 & 35,00 \\
\hline & $\mathrm{M}_{10}$ & 44,96 & 33,76 & 94,53 & 36,68 & 86,68 & 91,95 & 79,94 & 13,47 & 04,33 & 06,23 & 30,37 & 42,75 & 35,56 \\
\hline & $\mathrm{M}_{12}$ & 49,19 & 40,91 & 96,77 & 52,24 & 86,68 & 91,95 & 75,38 & 13,47 & 04,33 & 05,87 & 30,37 & 42,75 & 35,59 \\
\hline
\end{tabular}

Kandungan BK dan SK cendrung meningkat sejalan dengan meningkatnya umur tanaman dan diturunkannya level pemupukan, diperkirakan karena unsur $\mathrm{N}$ yang sifatnya sangat mobil di dalam tanah dapat mempermudah akar untuk mengabsorbsi air dalam tanah, menyebabkan tanaman lebih banyak mengandung air sehingga dapat menghambat terjadinya lignifikasi pada bagian tanaman. Selanjutnya bertambahnya umur tanaman menyebabkan tanaman memasuki fase renesance dimana tanaman telah berada pada masa penuaan sehingga menyebabkan bagian tanaman mengandung selulosa dan lignin yang tinggi.

Kandungan PK tertinggi sebesar 16,80\% sedangkan kandungan BO tertinggi sebesar 93,82\% yang dihasilkan dari perlakuan N15M2. Hal ini diduga karena pengaruh ketersediaan nitrogen dalam tanah yang cukup, dimana $\mathrm{N}$ merupakan unsur yang paling banyak terakumulasi dalam bahan organik karena merupakan unsur yang penting dalam sel mikroba yang terlibat dalam proses perombakan bahan organik tanah. Umumnya, makin tua umur tanaman maka makin berkurang kadar proteinnya dan serat kasarnya makin tinggi. Susetyo et al., 1994 dikutip Widayanti, 2008 menyatakan bahwa tanaman pada umur muda kualitas lebih baik karena serat kasar lebih rendah, sedangkan kadar proteinnya lebih tinggi. Semakin lama umur panen tanaman maka kandungan serat kasarnya semakin tinggi, sebaliknya terlalu awal atau dilakukan pemanenan pada umur yang pendek, hijauan tersebut akan selalu dalam keadaan muda sehingga kandungan protein dan kadar airnya tinggi tetapi kadar seratnya rendah. Selanjutnya Jamarun (2006) berpendapat bahwa persaingan antara tanaman 


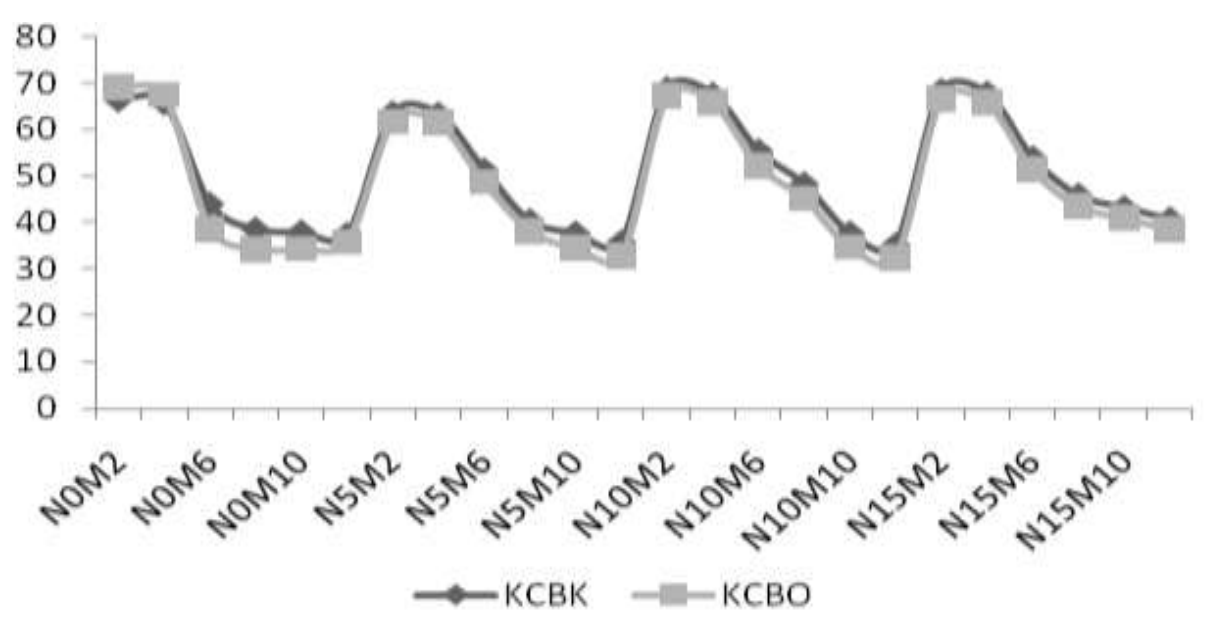

Grafik 1. Hubungan antara pemupukan $\mathrm{N}$ dan umur tanaman dengan KCBK dan KCBO Rumput s.plumosum var.timorense.

tidak terjadi selama kandungan air, hara dan cahaya matahari dalam keadaan serba lebih bagi kebutuhan tanaman.

\section{Kecernaan Bahan Kering dan Bahan Organik}

Tingkat kecernaan nutrisi oleh ternak dipengaruhi oleh kandungannya, umur tanaman serta bagian tanaman itu sendiri. Dalam hal ini hijauan pakan yang tua memiliki lignin yang tinggi sehingga mengandung serat kasar tinggi akan lebih sulit dicerna dibandingkan dengan tanaman yang lebih muda. Begitu pula dengan bagian batang tanaman lebih sulit dicerna dari pada bagian daun karena batang lebih banyak mengandung dinding sel yang sulit dicerna. Tren hubungan antara perlakuan pupuk $\mathrm{N}$ dan umur tanaman dengan nilai KCBK, KCBO dari hasil penelitian ini dapat dilihat pada Grafik 1.

Grafik 1 memperlihatkan bahwa KCBO berkolerasi positif dengan KCBK dimana jika KCBK tidak berbeda nyata akan mengakibatkan KCBO tidak berbeda nyata juga. Hal ini disebabkan bahan kering disusun oleh bahan organik dan anorganik. Bahan organik disusun oleh karbohidrat, protein kasar, lemak dan vitamin. Ifradi et.all (2012) juga menyatakan bahwa meningkatnya bahan kering menyebabkan kecernaan bahan organik juga meningkat karena kecernaan bahan kering berbanding lurus dengan kecernaan bahan organik. Hasil penelitian menunjukkan bahwa total $\mathrm{KCBO}$ dan KCBK tertinggi terdapat pada perlakuan N10M4 masingmasing sebesar 67,98 dan $68,84 \%$. Hasil uji Duncan diketahui bahwa baik secara mandiri maupun kombinasi interaksi kedua faktor tersebut, sangat berpengaruh nyata $(\mathrm{P}<0,01)$ terhadap KCBO dan KCBK. Hal ini dimungkinkan karena tanaman yang masih muda maka lebih tinggi nilai KCBO karena selulosa dan hemiselulosa yang ada dalam hijauan dapat didegradasi dan dimanfaatkan oleh mikroba rumen. Sutardi dikutip Koten (2013) mengemukakan bahwa BK tercerna sebagian besar terdiri dari Bahan Organik. KCBO berdampak pada konsumsi BO, konsumsi SK dan konsumsi PK. Dengan demikian maka sama halnya dengan kecernaan BK tanaman, dimana bagian tanaman yang memiliki nilai PK tinggi maka kecernaan BO juga tinggi. Menurut Ifradi et al (2012) banyaknya unsur hara yang terserap oleh tanaman maka fotosintesis akan meningkat sehingga makin banyak pula karbohidrat yang dihasilkan oleh tanaman yang akan membantu pembentukan batang dan daun tanaman.

\section{KESIMPULAN}

Rumput Sorghum plumosum var. timorense merupakan pakan lokal pulau timor yang sudah beradaptasi dengan kondisi kekeringan. Hasil penelitian membuktikan bahwa perlakuan pupuk urea sebanyak 150 $\mathrm{kg} / \mathrm{ha}$ dan umur panen 56 hari, menghasilkan 
produksi yang tinggi dan kualitas hijauan terbaik. Hal ini terjadi karena kondisi NTT yang kering dapat menyebabkan cepatnya penuaan tanaman sehingga dapat menurunnya kualitas dan produksi hijauan.

\section{DAFTAR PUSTAKA}

Achmadi, J. 2008. Nutrisi Reproduksi. Badan Penelitian Universitas Diponegoro. Semarang.

Ari T, Purwanto, Budiyono. 2013. Efisiensi penggunaan pupuk $\mathrm{N}$ untuk pengurangan kehilangan nitrat pada lahan kering. Proseding Seminar Nasional Pengelolaan Sumber Daya Alam dan Lingkungan.

Dami Dato, T.O. 2009. Eksploitasi peningkatan nilai gizi Rumput Kume (Sorghum plumosum var. timorense) kering dengan hidrolisis alkalin alamiah dan imbuhan probiotik sebagai pakan Sapi Bali di Nusa Tenggara Timur. Desertasi Pascasarjana Universitas Padjajaran, Bandung.

Ifradi., Evitayani., A. Fariani., L. Warly., Suyitman., S.Yani., Emikasmira. 2014. Pengaruh dosis pupuk N, P dan K terhadap kecernaan secara in vitro rumput gajah (Penisetum purpureum) cv Taiwan yang diinokulasi CMA Glomus manihotis pada lahan bekas tambang batubara. Jurnal Peternakan Indonesia. 14 (1). 279-285.

Jamarun, N. 2006. Produksi dan kandungan gizi Rumput Gajah (P.purpureum) dan Rumput Raja (P.purpupoides) yang ditumpangsarikan dengan tanaman jati. Jurnal Peternakan Indonesia. 11 (2):151157.

Kamlasi, Y. 2014. Pola pertumbuhan dan nutrisi Rumput Kume (Sorghum plumosum var. timorense) pada lingkungan alamiahnya disertai manajemen pemotongan. Tesis. Program Pasca Sarjana Ilmu Peternakan Universitas Nusa Cendana. Kupang.
Koten, B. 2013. Tumpangsari legum Arbila (Phaseolus Lunatus L) berinokulum rizobium dengan sorgum (Sorghum bicolor (L) Moench) dalam upaya meningkatkan produktivitas hijauan pakan ruminansia. Desertasi. Program Pasca Sarjana Fakultas Peternakan Universitas Gajah Madah. Yogyakarta.

Madarisa, F., Iskandar,L., Deswita, A. 2007. Analisa potensi bahan pakan lokal untuk pengembangan ternak sapi potong di Sumatera Barat. Jurnal Peternakan Indonesia. 12 (3):182-194.

Mansyur., L. Abdullah., H.Djuned., A.R.Tarmidi., T. Dhalika. 2006. Pengaruh interval pemotongan Rumput Brachiaria humidicola (Rendle) Scweick terhadap konsentrasi amonia dan asam lemak terbang (in vitro). Jurnal Peternakan Indonesia. 11 (1):50-56.

Mullik, M. L. 2011. Sistem Produksi Sapi Gembala Berkelanjutan. Integrasi IklimTanah-Tanaman-ternak. Undana Press, Kupang.

Sowmen, S., Abdullah, L., Karti P.D.M., dan Soepandi D. 2014. Adaptasi legum pohon yang diinokulasi dengan fungi Mikorisa arbuskular (FMA) saat cekaman kekeringan. Jurnal Peternakan Indonesia. 16 (1):46-54.

Widayanti, A. 2008. Efek pemotongan dan pemupukan terhadap produksi dan kualitas borreria alata (aubl.) sebagai hijauan makanan ternak kualitas tinggi. Skripsi Fapet IPB, Bogor.

Yoku,O., D.Soetrisno, R. Utomo dan S.A. Siradz. 2007. Pengaruh perlakuan jarak tanam dan pemupukan NPK terhadap produksi Rumput Sudan (Sorghum sudanese). Jurnal Agritek. 15: 81-87.

Zain, Erpomen dan Kartini. 2007. Amoniasi daun kelapa sawit dengan beberapa taraf urea dan pengaruhnya terhadap kandungan gizi dan kecernaan secara in vitro. Jurnal Peternakan Indonesia. 12 (3):195-200. 